\title{
Persistent Synaptic Scaling Independent of AMPA Receptor Subunit Composition
}

\author{
Haider F. Altimimi and David Stellwagen \\ Centre for Research in Neuroscience, Department of Neurology and Neurosurgery, The Research Institute of the McGill University Health Centre, Montreal, \\ Quebec H3G 1A4, Canada
}

Despite long-standing evidence that the specific intracellular domains of AMPA-type glutamate receptor (AMPAR) subunits are critical for trafficking, it has recently been demonstrated that there is no absolute requirement for any AMPAR subunit for the receptor insertion underlying LTP. It is unclear whether this holds true to other forms of plasticity. Homeostatic synaptic plasticity (HSP) is an important form of negative feedback that provides stability to neuronal networks, and results at least in part from the insertion of AMPARs into glutamatergic synapses following chronic reductions in neuronal activity. Similar to LTP, the GluA1 subunit has been suggested to be the requisite subunit for HSP-induced AMPAR insertion and acute treatment with signaling molecules that underlie some forms of HSP results in the preferential incorporation of GluA2-lacking receptors. However, knockdown experiments have instead implicated a requirement for the GluA2 subunit. Here we re-examined the requirement for specific AMPAR subunit during chronic tetrodotoxininduced HSP using hippocampal cultures derived from AMPAR subunit knock-out mice. We observed HSP in cultures from GluA1 ${ }^{-/-}$, $\mathrm{GluA}^{-1-}$, and GluA2 ${ }^{-1-} \mathrm{GluA}^{-1-}$ mice, and conclude that, as with LTP, there is no subunit requirement for HSP.

\section{Introduction}

Plasticity of excitatory synaptic transmission is in large part mediated by changes in the content of AMPA-type glutamate receptors (AMPARs) in the postsynaptic plasma membrane (Kerchner and Nicoll, 2008). Consequently, there has been intense investigation into the regulation of AMPAR trafficking, primarily focused on the differential contribution of the various AMPAR subunits. AMPARs are heteromultimers, comprised of the subunits GluA1-4. In the CA1 region of the hippocampus, AMPARs are principally composed of GluA1-GluA2 heteromers, with a smaller contribution of GluA2-GluA3 heteromers and GluA1 homomers (Wenthold et al., 1996; Lu et al., 2009; Rozov et al., 2012). The divergent cytosolic C-terminal domains of the subunits contain binding motifs for a variety of interacting proteins thought to contribute differentially to trafficking of AMPARs (Shepherd and Huganir, 2007). Based on those differences in the C-terminal domains, a subunits-specificity rule for AMPAR trafficking has emerged, which posits that AMPARs containing GluA2 are functionally incorporated into the synapse under basal conditions, whereas those containing GluA1 are excluded from the synapse and are functionally incorporated only with an in-

\footnotetext{
Received March 13, 2013; revised May 23, 2013; accepted June 10, 2013

Author contributions: H.F.A. and D.S. designed research; H.F.A. and D.S. performed research; H.F.A. and D.S. analyzed data; H.F.A. and D.S. wrote the paper.

This work was supported by the Canadian Institutes of Health Research, and the Natural Sciences and Engineering Research Council of Canada (D.S.) and the Heart and Stroke Foundation Canada (H.F.A.). We thank Virginie Biou for help with cultures, and R. Huganir for reagents.

The authors declare no competing financial interests.

Correspondence should be addressed to Dr David Stellwagen, Centre for Research in Neuroscience, The Research Institute of the McGill University Health Centre, Livingston Hall Room L7-217, 1650 Cedar Avenue, Montréal, Québec H3G 1A4, Canada. E-mail: david.stellwagen@mcgill.ca.

DOI:10.1523/JNEUROSCI.1102-13.2013

Copyright $\odot 2013$ the authors $\quad 0270-6474 / 13 / 3311763-05 \$ 15.00 / 0$
}

crease in neuronal activity, such as in LTP (Hayashi et al., 2000; Passafaro et al., 2001; Shi et al., 2001). GluA1 dominates GluA2 in trafficking according to this model, and is the key for activitydependent synaptic insertion (Passafaro et al., 2001; Shi et al., 2001). However, recent experiments demonstrate that no subunit, neither GluA1 nor GluA2, is required for synaptic incorporation of AMPARs or for LTP (Kim et al., 2005; Panicker et al., 2008; Granger et al., 2013). This challenges the notion of subunit specificity for other forms of synaptic plasticity.

Homeostatic synaptic plasticity (HSP), or synaptic scaling, is an important form of plasticity that acts in opposition to standard Hebbian plasticity (LTP and LTD) to normalize synaptic drive (Turrigiano, 2012). Much like Hebbian plasticity, HSP is thought to be mediated in a large part through changes in postsynaptic AMPAR content (Lee, 2012). Most work on HSP has focused on the scaling up of glutamatergic synapses, induced by the chronic reduction of neuronal activity. Mechanistic insight from these studies has suggested that GluA1, as in LTP, may play the predominant role. Several forms of activity deprivation cause the preferential increase in surface expression of GluA1 (Thiagarajan et al., 2005; Sutton et al., 2006; Hou et al., 2008; GarciaBereguiain et al., 2013). Moreover, factors that have been shown to be required for scaling up appear to target GluA1 for increased surface expression (Stellwagen et al., 2005; Stellwagen and Malenka, 2006; Aoto et al., 2008). However, interfering with GluA1 trafficking only reduced the magnitude of scaling up in neocortical cultures, whereas RNAi-mediated knockdown of GluA2 completely abrogated scaling up (Gainey et al., 2009). In light of the recent data demonstrating that LTP does not require any specific AMPAR subunit and can be expressed in the absence of AMPARs altogether (Granger et al., 2013), we have reexamined the AMPAR subunit requirement in the hippocampal 
homeostatic response to network inactivity. Similar to LTP, we find no requirement for any particular AMPAR subunit.

\section{Materials and Methods}

Animals and neuronal culture. All procedures were performed in accordance with the guidelines of the Canadian Council for Animal Care and the Montreal General Hospital Animal Care Committee. Cultures were prepared from $\mathrm{GluA}^{-1-}$, GluA2 ${ }^{-1-}$, GluA3 ${ }^{-1-}$, or GluA2 ${ }^{-1-} \mathrm{GluA}^{-1-}$, and compared with wild-type C57BL/6 mice. Hippocampi were dissected in cold HBSS from newborn (P0-P1) pups of either sex, trypsinized (0.05\% trypsin/ EDTA; Life Tech) for 15-20 min, triturated and seeded on coverslips precoated with polyD-lysine ( $10 \mu \mathrm{g} / \mathrm{ml}$; Sigma-Aldrich) in 24-well plates at $75-150 \times 10^{3}$ cells per well. Cultures were maintained in neurobasal supplemented with $0.5 \mathrm{~mm}$ Glutamax and 2\% v/v B27 (all from Life Tech). 5-Fluoro-2'-deoxyuridine: uridine (0.13:0.33 mg/ml; Sigma-Aldrich) was added between DIV4-6. Cultures were treated with $1 \mu \mathrm{M}$ TTX (Alomone Labs) for $2 \mathrm{~d}$ before testing at DIV12-15 or at DIV21.

Surface-labeling of AMPARs and image analysis. AMPAR surface staining and image analysis were done essentially as described previously (Stellwagen et al., 2005). The antiGluA1 antibody (1:1000; gift from R. Huganir,

Johns Hopkins University, Baltimore, MD) was used on fixed, nonpermeabilized cells. The anti-GluA2 antibody $(5-10 \mu \mathrm{g} / \mathrm{ml}$, clone $6 \mathrm{C} 4$, Millipore) was added to live cultures in conditioned medium for 15-20 min at $37^{\circ} \mathrm{C}$, washed with aCSF (see below), and fixed in $2.5 \%$ paraformaldehyde $/ 4 \%$ sucrose in aCSF. Cells were permeabilized with $0.1 \%$ Triton $\mathrm{X}-100$, and labeled for MAP2 $(0.5 \mu \mathrm{g} / \mathrm{ml}$, clone HM-2, GeneTex). Images were acquired using wide-field fluorescence or confocal laser scanning microscopy, using $63 \times$ objective and identical laser power and exposure settings for any given experiment. For analysis, the total area of AMPAR immunostaining was selected by thresholding, and normalized to total dendritic area (selected by using either background fluorescence or corresponding MAP2 signal). The percentage of dendritic area containing AMPARs was then compared between conditions.

Electrophysiology and mEPSC analysis. Patch-clamp recordings were performed in aCSF (in mM: $\mathrm{NaCl} 135, \mathrm{KCl} 3.5, \mathrm{CaCl}_{2} 2, \mathrm{MgCl}_{2} 1.3$, HEPES 10, D-glucose 20, $\mathrm{pH}$ adjusted to 7.3-7.4 with $\mathrm{NaOH}$ ), supplemented with TTX $(0.5 \mu \mathrm{M})$, picrotoxin $(100 \mu \mathrm{M})$, and D-APV $(25 \mu \mathrm{M})$. Borosilicate electrodes were filled with (in mM): $\mathrm{CsMeSO}_{4} 125, \mathrm{CsCl} 10$, HEPES 15, MgATP 4, $\mathrm{Na}_{3} \mathrm{GTP} 0.4, \mathrm{Na}_{2}$-phosphocreatine 5, Trisphosphocreatine 5, EGTA 0.6, $\mathrm{CaCl}_{2} 0.05, \mathrm{pH}$ 7.2. Cells were held at -70 $\mathrm{mV}$; only recordings with stable access resistance ( $8-25 \mathrm{M} \Omega$ ) were included, and cells with membrane resistance $<150 \mathrm{M} \Omega$, or very low mEPSC frequency $(<0.2 \mathrm{~Hz})$ were excluded from further analysis. Clampfit 10 was used to identify mEPSCs using template matching, with a threshold of $7 \mathrm{pA}$ ( $>2 \times$ root mean square of baseline noise). For cumulative distribution plots of mEPSC amplitude, an equal number of mEPSCs (35 per cell) was randomly selected from each cell, then rankordered and averaged for each condition. Multiplicative scaling was verified by plotting the TTX-treated mEPSC amplitudes against respective control and using linear regression to obtain a slope factor to transform the TTX distribution.

Data analysis. All data presented were pooled from 2-6 culture batches. Data are presented as \pm SEM and statistical significance considered at $p<0.05$. Imaging data were compared using an unpaired Student's $t$ test; multiple comparisons of electrophysiology data were done using the Wilcoxon test and the Kolmogorov-Smirnov (K-S) test used for cumulative distributions of mEPSC amplitudes.
B
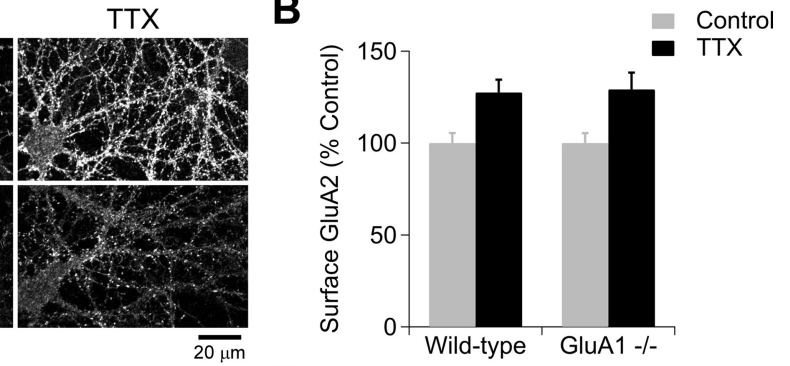

D

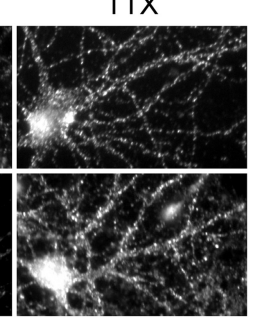

(1)

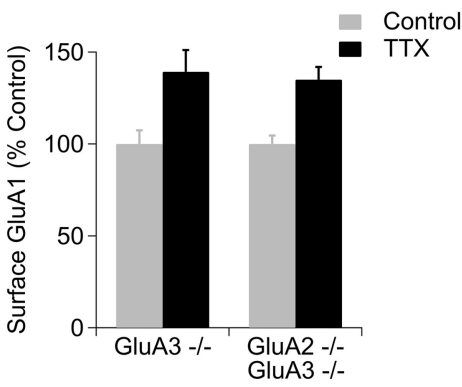

Figure 1. AMPAR surface trafficking in response to inactivity is independent of subunit identity. $\boldsymbol{A}$, Example images of cellsurface labeling of GluA2 in wild-type and $\mathrm{GluA} 1^{-1-}$ neurons, control or treated for $2 \mathrm{~d}$ with TTX. $B$, Summary data showing an increase in AMPAR surface levels with $2 \mathrm{~d}$ TTX treatment over control in wild-type and GluA1 ${ }^{-1-}$ cultures $(p<0.01, n=60$

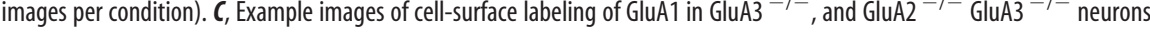
rol and treated for $2 \mathrm{~d}$ with TTX. D, Summary data showing an increase in AMPAR surface levels with TTX treatment over contro in GluA3 ${ }^{-1-}(p<0.01)$, and GluA2 ${ }^{-1-}$ GluA3 $^{-1-}$ cultures $(p<0.001, n=30-61$ images per condition).

\section{Results}

To address the question of AMPAR subunit requirement for AMPAR insertion during chronic activity blockade, we treated dissociated hippocampal cultures from newborn mice with constitutive deletions in AMPAR subunits with TTX for a period of $2 \mathrm{~d}$ before testing between DIV12-15. For wild-type and GluA1 ${ }^{-/-}$mice, we assessed the surface expression of AMPARs using an antibody against the N-terminus of GluA2 on nonpermeabilized cells. As expected, $2 \mathrm{~d}$ of activity blockade results in a significant increase in the surface expression of AMPARs in wildtype (Fig. $1 A, B$; wild-type TTX-treated $128 \pm 7 \%$ of control, $p<$ 0.01). Consistent with previous reports (Zamanillo et al., 1999; Lu et al., 2009), the surface expression of AMPARs on neurons from GluA1 ${ }^{-1-}$ cultures was greatly reduced with respect to wild-type cultures ( $\sim 15 \%$ of wild-type surface levels). However, we still found that a $2 \mathrm{~d}$ TTX treatment produced a comparable increase over control in the surface expression of AMPAR (Fig. 1; GluA1 $^{-1-}$ TTX-treated $129 \pm 9 \%$ of control, $\left.p<0.01\right)$. These results appear to discount a critical role for GluA1 in the increase in surface trafficking of AMPAR in response to activity blockade, in agreement with the results of (Gainey et al., 2009). However, when we tested GluA3 ${ }^{-1-}$, as well as GluA2 ${ }^{-1-}$; GluA3 ${ }^{-1-}$ double-mutant cultures for scaling up, we still found a robust increase in surface trafficking of AMPAR (labeled using an $\mathrm{N}$-terminus anti-GluA1 antibody) in response to $2 \mathrm{~d}$ TTX treatment (Fig. 1 C,D: GluA3 ${ }^{-1-}$ TTX-treated $139 \pm 12 \%$ of control, $p<0.01$, GluA2 ${ }^{-1-}$ GluA3 $^{-1-} 135 \pm 7 \%$ of control, $p<0.001$ ). Unlike for GluA1, basal surface expression of AMPARs is unaffected in GluA2 ${ }^{-1-}$ cultures ( $103 \pm 0.5 \%$ of control). To ensure that this is true for mature synapses, we also tested synaptic scaling at DIV21. Consistent with our results on younger cultures, we observed a significant increase in the surface expression of GluA2 for wild-type and GluA1 ${ }^{-/-}$cultures, and in the surface expression of GluA1 for GluA2 ${ }^{-/-}$cultures (wild-type: TTX-treated $138 \pm 7 \%$ of control, $p<0.001$; GluA1 ${ }^{-/-}$: TTX-treated $130 \pm$ 


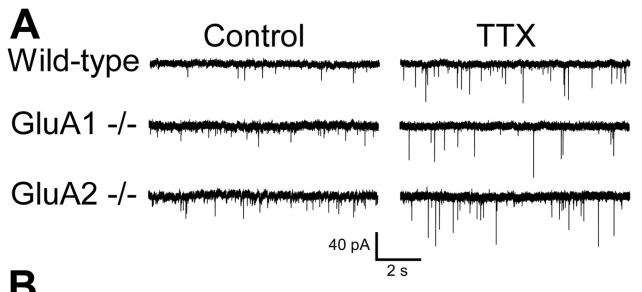

B

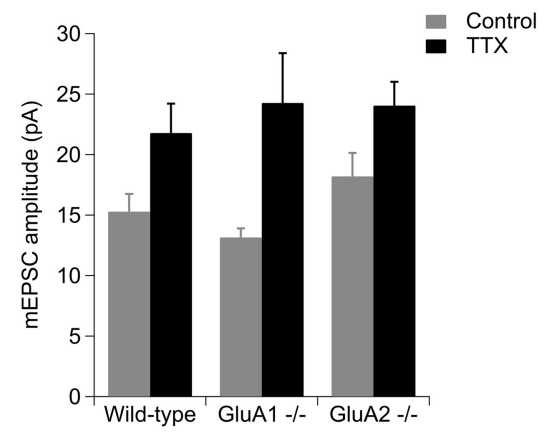

Figure 2. Synapticscaling is independent of AMPAR subunitidentity. $A$, Example traces from wild-type, GluA1 ${ }^{-1-}$, and GluA2 ${ }^{-1-}$ neurons, control or treated for $2 \mathrm{~d}$ with TTX. $\boldsymbol{B}$, Mean mEPSC amplitudes for wild-type, GluA ${ }^{-1-}$, and GluA2 $2^{-1-}$ increased significantly with $2 \mathrm{~d}$ TTX treatment (wild-type control $n=18, \operatorname{TTX}_{n}=20, p<0.01$;luA1 $^{-1-}$ control $n=10$, $\operatorname{TTX} n=10, p=0.01$; GluA2 ${ }^{-\prime-}$ control $n=17, \operatorname{TTX} n=19, p=0.04$ ).

$8 \%$ of control, $p=0.01$; GluA2 $2^{-1-}$ : TTX-treated $130 \pm 10 \%$ of control, $p=0.02 ; n=48-65$ images per condition). Therefore, unlike acute RNAi knockdown of GluA2 (Gainey et al., 2009), constitutive loss of GluA2 does not prevent the scaling-induced increase in AMPAR surface expression.

To verify that the increase in surface trafficking of AMPAR in response to $2 \mathrm{~d}$ TTX treatment was associated with scaling up of synaptic strength, we recorded mEPSCs from wild-type, GluA1 ${ }^{-/-}$, and GluA2 ${ }^{-/-}$cultures following chronic activity blockade. In all three genetic backgrounds, we observed a significant increase in mEPSC amplitude in response to $2 \mathrm{~d}$ TTX treatment (Fig. 2: wild-type, control $14.2 \pm 1.2 \mathrm{pA}, n=18$, TTX $21.5 \pm 2.3 \mathrm{pA}, n=20, p<0.01$; GluA1 ${ }^{-1-}$, control $13.2 \pm 0.7$ pA, $n=10$, TTX $24.3 \pm 4.1 \mathrm{pA}, n=10, p=0.01$; $\mathrm{GluA}^{-l-}$, control $17.7 \pm 1.9 \mathrm{pA}, n=17$, TTX $24.3 \pm 2.1 \mathrm{pA}, n=19, p=$ $0.04)$. There was no significant difference in the baseline mEPSC amplitude among the various genotypes.

Although not significant, we did observe an increase in mEPSC frequency with $2 \mathrm{~d}$ TTX treatment in the case of wildtype and GluA2 ${ }^{-1-}$ cultures (wild-type, control $2.3 \pm 0.6 \mathrm{~Hz}$, $n=18$, TTX $5.4 \pm 1.3 \mathrm{~Hz}, n=20, p=0.08$; GluA1 ${ }^{-1-}$, control $2.3 \pm 0.7 \mathrm{~Hz}, n=10$, TTX $2.0 \pm 0.6 \mathrm{~Hz}, n=10, p=0.68$; GluA2 $^{-/-}$, control $2.4 \pm 0.6 \mathrm{~Hz}, n=17$, TTX $4.5 \pm 1.0 \mathrm{~Hz}, n=$ $19, p=0.10)$. The trend of increase in mEPSC frequency may be related to the relatively mature state of our dissociated mouse cultures; it has been reported previously that although activityblockade at early stages of in vitro culture development scales quantal amplitude, in more mature cultures the same activity deprivation additionally recruits presynaptic mechanisms (Wierenga et al., 2006; Han and Stevens, 2009).

We further analyzed the nature of synaptic scaling in the three genetic backgrounds by randomly extracting a subset of mEPSC amplitude values and plotting the mean ranked TTX distribution versus control for each genotype (Fig. $3 A$ ). In all cases, the control distribution was reproduced by a scalar multiplication of its respective TTX distribution (scaling factors: wild-type 1.54, $\mathrm{GluA}^{-/-} 2.46$ GluA2 $^{-/-} 2.01$ ). Although Kolmogorov-Smir- nov testing revealed a significant difference in the cumulative fraction distribution of mEPSC amplitudes between control and TTX-treated cells for all three genotypes, there was no statistically significant difference when the TTX distribution was scaled down by the slope factor and compared against its control distribution (Fig. 3B). This argues that the scaling observed in all genotypes represents a multiplicative increase in all synapses of the neuron, as has been reported for neocortical neurons (Turrigiano et al., 1998; Gainey et al., 2009; Goel et al., 2011).

\section{Discussion}

We demonstrated here that constitutive loss of GluA1 or GluA2 (and GluA3) does not lead to a deficit in surface trafficking of AMPAR in response to prolonged activity deprivation, and moreover that synaptic scaling of quantal amplitude is preserved in neuronal cultures from those animals. This suggests that scaling up can recruit AMPARs regardless of subunit composition and is corroborative to the recent finding that AMPAR subunits are dispensable for trafficking and plasticity in the context of LTP (Granger et al., 2013).

HSP is an important form of plasticity that acts to regulate neuronal activity in networks (Turrigiano, 2012). Although induction is mechanistically distinct from Hebbian plasticity, HSP has similar expression as a change in synaptic AMPAR content (Lee, 2012). Therefore, principles of AMPAR trafficking may be similar, and HSP may interact in interesting ways with other forms of plasticity (Arendt et al., 2013). Recent work has demonstrated that Hebbian-type synaptic strengthening requires abundant surface expression of AMPARs, but does not require any specific AMPAR subunit, shifting the focus of receptor trafficking from the multimeric nature of the AMPAR, to the structure and protein composition of the glutamatergic postsynapse (Granger et al., 2013).

Previous studies investigating the mechanism of HSP in response to activity deprivation have suggested the importance of GluA1, and specifically its C-terminal domain, in scaling up, much like in LTP (Zamanillo et al., 1999; Hayashi et al., 2000; Passafaro et al., 2001; Lee et al., 2003; Thiagarajan et al., 2005; Stellwagen and Malenka, 2006; Sutton et al., 2006; Aoto et al., 2008; Hou et al., 2008; Goel et al., 2011; Garcia-Bereguiain et al., 2013). However, the study by Gainey et al. (2009) using a dominant-negative strategy of interfering with the trafficking of AMPARs through overexpression of GluA1 or GluA2 C-terminal domains, showed that although overexpression of GluA1 C-terminal domain only partially reduced the magnitude of synaptic scaling up, overexpression of GluA2 C-terminal domain completely abrogated the response to TTX. The GluA1 C-terminal domain has been used in the past to interfere with LTP expression, presumably through interference with PDZmediated interactions at the extreme C-terminus (Shi et al., 2001); however, knock-in animals lacking the PDZ ligand showed normal LTP (Kim et al., 2005), highlighting the importance of using different complementary strategies to assess lossof-function in biological systems (Boehm et al., 2006).

The study of Gainey et al. (2009) also demonstrated that RNAi-mediated knockdown of GluA2 abolished synaptic scaling in response to TTX. There are several possible explanations for the seeming discrepancy between their study and our current work. First, the cultures of Gainey et al. (2009) were from rat neocortex, whereas we used mouse hippocampal cultures, and it is plausible that the differences could be attributed to brain region-dependent trafficking rules or differences in culture conditions. However, no fundamental differences between HSP in 
the two systems have been reported. More likely, the difference is due to the AMPAR subunit loss-of-function approach used by the two studies; we opted to use constitutive knock-outs, rather than relatively acute knockdown using RNAi. This raises the possibility of developmental compensation in our approach. The regulation of synaptic AMPARs is a critical function of neurons, and other trafficking routes could be accessed when the normal pathways are removed. Nonetheless it does argue that no AMPAR subunit or binding partner is absolutely required for regulated synaptic insertion seen in HSP or in LTP, although it does not preclude any particular subunit or interactor from being the key mediator when all subunits are present.

It could be argued that constitutive knock-outs have fundamentally altered signaling. However, despite GluA2 knock-outs having $\mathrm{Ca}^{2+}$ permeable basal synaptic currents that could be a potential source of anomalous signaling, previous studies have demonstrated that basal and activitydependent AMPAR trafficking are not altered in hippocampal slice preparations in these mouse models (Jia et al., 1996; Meng et al., 2003; Panicker et al., 2008). Further, the dissociated cultures of GluA1 ${ }^{-1-}$ used here have recapitulated one of the main findings in situ from GluA1 ${ }^{-/-}$hippocampal slices (Zamanillo et al., 1999; Lu et al., 2009), that surface expression of AMPAR is greatly reduced with respect to wild-type cultures ( $\sim 15 \%$ of wild-type surface levels), whereas basal synaptic strength remains largely intact (Fig. 2B). This suggests that the extrasynaptic pool of receptors is greatly diminished, though the synaptic content of AMPARs remains relatively unchanged, and raises the question of how is it that scaling up is conserved in GluA1 ${ }^{-/-}$neurons, when the decrease in extrasynaptic AMPAR renders those cells deficient in LTP expression (Granger et al., 2013). One of the key differences between LTP and HSP is the time scale over which these phenomena operate. Although LTP is a relatively rapid form of plasticity, and likely dependent on a large available pool of extrasynaptic receptors to traffic into the synapse, scaling up operates over a much longer period, and is dependent on transcription (Ibata et al., 2008; Jakawich et al., 2010). Hence, over the prolonged period of inactivity, there may be sufficient newly translated AMPARs (or translation of factors that increase AMPAR trafficking) to sustain scaling up. Further, the gradual nature of the receptor accumulation may allow a smaller reserve pool of extrasynaptic receptors to suffice.

The results presented here show clearly that in hippocampal pyramidal neurons, one of the most widely studied neuronal cellular models, there is no AMPAR-subunit dependence for HSP; however, it should be noted that this may only apply to scaling up. Indeed
B
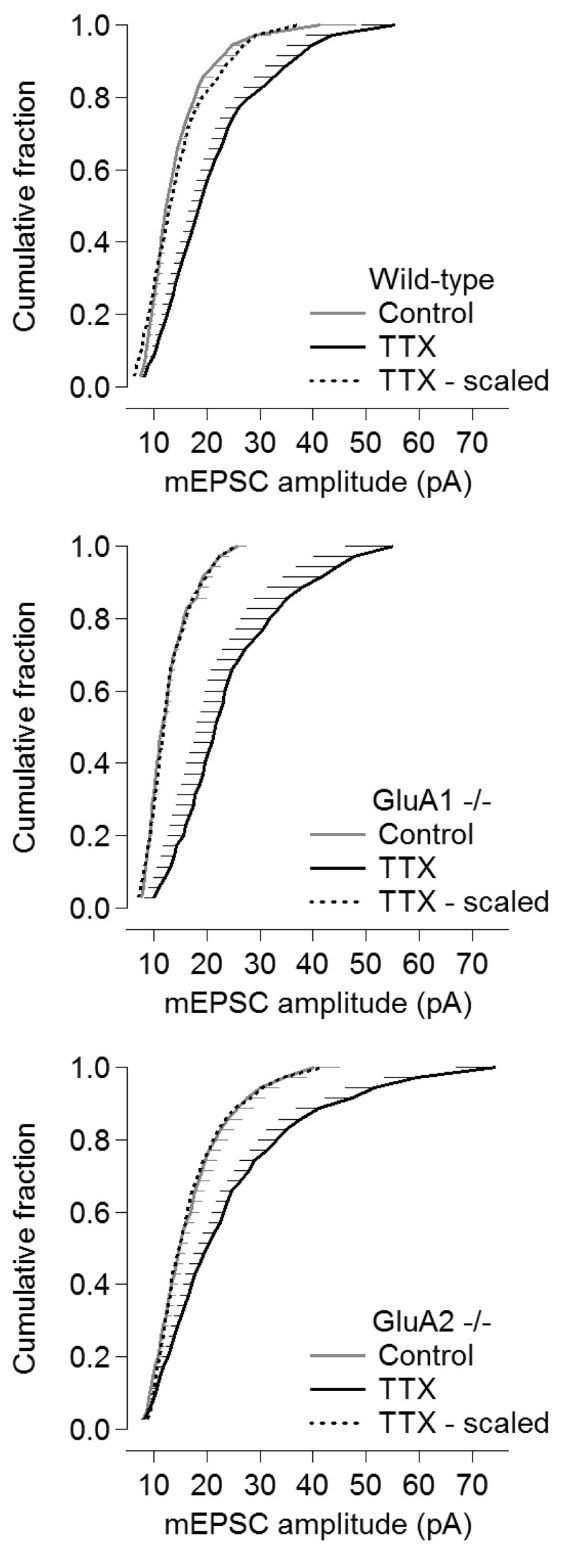

Figure 3. Synaptic scaling remains multiplicative in the absence of GluA1 or GluA2. $\boldsymbol{A}$, Randomly selected mEPSCs for $2 \mathrm{~d}$ TTX-treated were ranked and averaged, and compared against control. Linear regression yielded slope factors of: TTX $=$ control $X$ 1.54 for wild-type, $\mathrm{TTX}=2.46 \times$ control for GluA1 $^{-1-}$, and TTX $=2.01 \times$ control for GluA2 $^{-1-}$. $B$, Cumulative fraction for ranked averaged $m E P S C$ amplitudes ( \pm SEM) was plotted for control (gray line) and TTX (black line) for each genotype; $K-S$ testing scaled down by respective slope factor (dashed black line), and when compared versus control yielded $p$ values of 0.62 for wild-type, 1.00 for GluA1 ${ }^{-1-}$, and 1.00 for GluA2 ${ }^{-1-}$.

several studies have demonstrated that, analogous to the case with Hebbian-type plasticity, scaling up and scaling down are mechanistically distinct processes. Deficiency in the factors that regulate scaling up, do not affect scaling down (Stellwagen and Malenka, 2006; Pratt et al., 2011). Moreover, cell-autonomous scaling down in hippocampal organotypic slices has been shown to require the GluA2, but not the GluA1, subunit (Goold and Nicoll, 2010). That this study demonstrated a requirement for the GluA2 subunit in scaling down, using constitutive genetic knock-out, argues against developmental compensation in this mouse model. This suggests that the trafficking rules governing endocytosis may be distinct from those regulating exocytosis and synaptic insertion, though it should be noted that LTD is normal in GluA2 ${ }^{-1-}$ mice (Jia et al., 1996). 
Together with the recent demonstration that LTP does not require any specific AMPAR subunit (Granger et al., 2013), these data should shift the focus in studying AMPAR trafficking in the context of glutamatergic synaptic plasticity from the receptor subunit composition, to the structure and protein composition of the synapse. To this end, it has been shown that excitatory glutamatergic HSP does involve structural changes in synaptic structure and the composition of the postsynaptic density, including transmembrane AMPAR regulatory proteins or TARPs (O’Brien et al., 1998; Ehlers, 2000; Sun and Turrigiano, 2011; Shin et al., 2012).

\section{References}

Aoto J, Nam CI, Poon MM, Ting P, Chen L (2008) Synaptic signaling by all-trans retinoic acid in homeostatic synaptic plasticity. Neuron 60: 308-320. CrossRef Medline

Arendt KL, Sarti F, Chen L (2013) Chronic inactivation of a neural circuit enhances LTP by inducing silent synapse formation. J Neurosci 33:20872096. CrossRef Medline

Boehm J, Ehrlich I, Hsieh H, Malinow R (2006) Two mutations preventing PDZ-protein interactions of GluR1 have opposite effects on synaptic plasticity. Learn Mem 13:562-565. CrossRef Medline

Ehlers MD (2000) Reinsertion or degradation of AMPA receptors determined by activity-dependent endocytic sorting. Neuron 28:511-525. CrossRef Medline

Gainey MA, Hurvitz-Wolff JR, Lambo ME, Turrigiano GG (2009) Synaptic scaling requires the GluR2 subunit of the AMPA receptor. J Neurosci 29:6479-6489. CrossRef Medline

Garcia-Bereguiain MA, Gonzalez-Islas C, Lindsly C, Butler E, Hill AW, Wenner P (2013) In vivo synaptic scaling is mediated by GluA2-lacking AMPA receptors in the embryonic spinal cord. J Neurosci 33:6791-6799. CrossRef Medline

Goel A, Xu LW, Snyder KP, Song L, Goenaga-Vazquez Y, Megill A, Takamiya K, Huganir RL, Lee HK (2011) Phosphorylation of AMPA receptors is required for sensory deprivation-induced homeostatic synaptic plasticity. PLoS One 6:e18264. CrossRef Medline

Goold CP, Nicoll RA (2010) Single-cell optogenetic excitation drives homeostatic synaptic depression. Neuron 68:512-528. CrossRef Medline

Granger AJ, Shi Y, Lu W, Cerpas M, Nicoll RA (2013) LTP requires a reserve pool of glutamate receptors independent of subunit type. Nature 493: 495-500. CrossRef Medline

Han EB, Stevens CF (2009) Development regulates a switch between postand presynaptic strengthening in response to activity deprivation. Proc Natl Acad Sci U S A 106:10817-10822. CrossRef Medline

Hayashi Y, Shi SH, Esteban JA, Piccini A, Poncer JC, Malinow R (2000) Driving AMPA receptors into synapses by LTP and CaMKII: requirement for GluR1 and PDZ domain interaction. Science 287:2262-2267. CrossRef Medline

Hou Q, Zhang D, Jarzylo L, Huganir RL, Man HY (2008) Homeostatic regulation of AMPA receptor expression at single hippocampal synapses. Proc Natl Acad Sci U S A 105:775-780. CrossRef Medline

Ibata K, Sun Q, Turrigiano GG (2008) Rapid synaptic scaling induced by changes in postsynaptic firing. Neuron 57:819-826. CrossRef Medline

Jakawich SK, Neely RM, Djakovic SN, Patrick GN, Sutton MA (2010) An essential postsynaptic role for the ubiquitin proteasome system in slow homeostatic synaptic plasticity in cultured hippocampal neurons. Neuroscience 171:1016-1031. CrossRef Medline

Jia Z, Agopyan N, Miu P, Xiong Z, Henderson J, Gerlai R, Taverna FA, Velumian A, MacDonald J, Carlen P, Abramow-Newerly W, Roder J (1996) Enhanced LTP in mice deficient in the AMPA receptor GluR2. Neuron 17:945-956. CrossRef Medline

Kerchner GA, Nicoll RA (2008) Silent synapses and the emergence of a postsynaptic mechanism for LTP. Nat Rev Neurosci 9:813-825. CrossRef Medline

Kim CH, Takamiya K, Petralia RS, Sattler R, Yu S, Zhou W, Kalb R, Wenthold R, Huganir R (2005) Persistent hippocampal CA1 LTP in mice lacking the C-terminal PDZ ligand of GluR1. Nat Neurosci 8:985-987. CrossRef Medline
Lee HK (2012) Ca-permeable AMPA receptors in homeostatic synaptic plasticity. Front Mol Neurosci 5:17. CrossRef Medline

Lee HK, Takamiya K, Han JS, Man H, Kim CH, Rumbaugh G, Yu S, Ding L, He C, Petralia RS, Wenthold RJ, Gallagher M, Huganir RL (2003) Phosphorylation of the AMPA receptor GluR1 subunit is required for synaptic plasticity and retention of spatial memory. Cell 112:631-643. CrossRef Medline

Lu W, Shi Y, Jackson AC, Bjorgan K, During MJ, Sprengel R, Seeburg PH, Nicoll RA (2009) Subunit composition of synaptic AMPA receptors revealed by a single-cell genetic approach. Neuron 62:254-268. CrossRef Medline

Meng Y, Zhang Y, Jia Z (2003) Synaptic transmission and plasticity in the absence of AMPA glutamate receptor GluR2 and GluR3. Neuron 39:163176. CrossRef Medline

O'Brien RJ, Kamboj S, Ehlers MD, Rosen KR, Fischbach GD, Huganir RL (1998) Activity-dependent modulation of synaptic AMPA receptor accumulation. Neuron 21:1067-1078. CrossRef Medline

Panicker S, Brown K, Nicoll RA (2008) Synaptic AMPA receptor subunit trafficking is independent of the $\mathrm{C}$ terminus in the GluR2-lacking mouse. Proc Natl Acad Sci U S A 105:1032-1037. CrossRef Medline

Passafaro M, Piëch V, Sheng M (2001) Subunit-specific temporal and spatial patterns of AMPA receptor exocytosis in hippocampal neurons. Nat Neurosci 4:917-926. CrossRef Medline

Pratt KG, Zimmerman EC, Cook DG, Sullivan JM (2011) Presenilin 1 regulates homeostatic synaptic scaling through Akt signaling. Nat Neurosci 14:1112-1114. CrossRef Medline

Rozov A, Sprengel R, Seeburg PH (2012) GluA2-lacking AMPA receptors in hippocampal CA1 cell synapses: evidence from gene-targeted mice. Front Mol Neurosci 5:22. CrossRef Medline

Shepherd JD, Huganir RL (2007) The cell biology of synaptic plasticity: AMPA receptor trafficking. Annu Rev Cell Dev Biol 23:613-643. CrossRef Medline

Shi S, Hayashi Y, Esteban JA, Malinow R (2001) Subunit-specific rules governing AMPA receptor trafficking to synapses in hippocampal pyramidal neurons. Cell 105:331-343. CrossRef Medline

Shin SM, Zhang N, Hansen J, Gerges NZ, Pak DT, Sheng M, Lee SH (2012) GKAP orchestrates activity-dependent postsynaptic protein remodeling and homeostatic scaling. Nat Neurosci 15:1655-1666. CrossRef Medline

Stellwagen D, Beattie EC, Seo JY, Malenka RC (2005) Differential regulation of AMPA receptor and GABA receptor trafficking by tumor necrosis factor-alpha. J Neurosci 25:3219-3228. CrossRef Medline

Stellwagen D, Malenka RC (2006) Synaptic scaling mediated by glial TNFalpha. Nature 440:1054-1059. CrossRef Medline

Sun Q, Turrigiano GG (2011) PSD-95 and PSD-93 play critical but distinct roles in synaptic scaling up and down. J Neurosci 31:6800-6808. CrossRef Medline

Sutton MA, Ito HT, Cressy P, KempfC, Woo JC, Schuman EM (2006) Miniature neurotransmission stabilizes synaptic function via tonic suppression of local dendritic protein synthesis. Cell 125:785-799. CrossRef Medline

Thiagarajan TC, Lindskog M, Tsien RW (2005) Adaptation to synaptic inactivity in hippocampal neurons. Neuron 47:725-737. CrossRef Medline

Turrigiano G (2012) Homeostatic synaptic plasticity: local and global mechanisms for stabilizing neuronal function. Cold Spring Harb Perspect Biol 4:a005736. CrossRef Medline

Turrigiano GG, Leslie KR, Desai NS, Rutherford LC, Nelson SB (1998) Activity-dependent scaling of quantal amplitude in neocortical neurons. Nature 391:892-896. CrossRef Medline

Wenthold RJ, Petralia RS, Blahos J II, Niedzielski AS (1996) Evidence for multiple AMPA receptor complexes in hippocampal CA1/CA2 neurons. J Neurosci 16:1982-1989. Medline

Wierenga CJ, Walsh MF, Turrigiano GG (2006) Temporal regulation of the expression locus of homeostatic plasticity. J Neurophysiol 96:2127-2133. CrossRef Medline

Zamanillo D, Sprengel R, Hvalby O, Jensen V, Burnashev N, Rozov A, Kaiser KM, Köster HJ, Borchardt T, Worley P, Lübke J, Frotscher M, Kelly PH, Sommer B, Andersen P, Seeburg PH, Sakmann B (1999) Importance of AMPA receptors for hippocampal synaptic plasticity but not for spatial learning. Science 284:1805-1811. CrossRef Medline 